\title{
Г.О. Абдикерова
}

Казахский национальный университет им. аль-Фараби, Казахстан, г. Алматы, e-mail: a.gulnapis@mail.ru

\section{СОЦИААЬНО-ГУМАНИТАРНОЕ ОБРАЗОВАНИЕ В ЭПОХУ ГАОБААИЗАЦИИ}

В статье рассматриваются перспективы развития социально-гуманитарного образования в условиях глобализации. Жизнь ^юдей меняется значительно в Аучшую сторону под влиянием глобализации, утверждает Аж. Ритцер (2018). Сегодня наиболее продвинутая часть молодежи использует позитивное влияние глобализации Аля своего становления и личностного роста, в то время как неуспешные становятся аутсайдерами и пополняют количество маргинальных слоев общества, угрожая социальной безопасности государства. Увеличение подростковой преступности, жестокости - это результат социального неблагополучия, нехватки среАств Аля получения качественного образования, достойной жизни.

Цель исследования - определить мировоззренческие приоритеты социально-гуманитарного образования в эпоху глобализации. Значимость исследования непосреАственно связана с актуализацией цивилизационного подхода наравне с модернистской. Результаты теоретического и эмпирического анализа показывают усиление социальных кризисов в казахстанском обществе, расслоение молодежного потенциала страны по уровню образования и культуры, мировоззренческим ценностям, а также усиливается разрыв между поколениями.

Только сильная экономика, возвышая потребность молодого поколения способны создавать условия Аля борьбы с социальными кризисами. Высокий уровень образования и культуры, богатый интелмектуальный и научный потенциал молодежи можно создавать только в условиях экономического роста и в атмосфере высокого морального состояния общества.

Кмючевые слова: молодежь, социально-гуманитарное образование, глобализация, мировоззренческие приоритеты, рыночное общество, рационализация.

\section{G.O. Abdikerova \\ Al-Farabi Kazakh National University, Kazakhstan, Almaty, e-mail: a.gulnapis@mail.ru \\ Social and humanitarian education in the age of globalization}

The article examines the prospects for the development of social and humanitarian education in the context of globalization. People's lives are changing significantly for the better under the influence of globalization, "says the American scientist J. Ritzer (2018). Today, the most advanced part of young people use the positive influences of globalization for their formation and personal growth, while the unsuccessful ones become outsiders and replenish the number of marginal layers of society, threatening the social security of the state. The increase in juvenile delinquency and cruelty is the result of social ill-being, a lack of funds for obtaining a quality education and a decent life.

The purpose of the study is to determine the worldview priorities of social and humanitarian education in the era of globalization. The significance of the study is directly related to the actualization of the civilizational approach on a par with the modernist one. The results of theoretical and empirical analysis show the intensification of social crises in Kazakhstani society, the stratification of the country's youth potential in terms of education and culture, worldview values, and the gap between generations is increasing.

Only a strong economy, raising the needs of the younger generation, is able to create conditions for combating social crises. A high level of education and culture, a rich intellectual and scientific potential of young people can be created only in conditions of economic growth and in an atmosphere of high moral state of society

Key words: youth, social and humanitarian education, globalization, worldview priorities, market society, rationalization. 


\section{Г.О. Абдикерова \\ Ә^-Фараби атындағы Қазақ, ұлттық университеті, Қазақстан, Алматы қ. \\ *e-mail: a.gulnapis@mail.ru}

\section{Жаһандану дәуіріндегі әлеуметтік-гуманитарлық білім}

Мақалада жаһандану жағдайында әлеуметтік-гуманитарлық білімнің даму перспективалары қарастырылады. «Жаһанданудың әсерінен адамдардың өмірі жақсы жағына қарай айтарлықтай өзгеруде» дейді америкалық ғалым Аж. Ритцер (2018). Қазіргі уақытта жастардың ең алдыңғы қатарлы бөлігі өздерінің қалыптасуы мен тұлғалық тұрғылан өсуі үшін жаһанданудың жағымды әсерін пайдаланады, ал сәтсіздікке ұшырағандар аутсайдерлерге айналады, мемлекеттің әлеуметтік қауіпсіздігіне қауіп төндіре отырып, қоғамның маргиналдық топтарының санын толықтырады. Кәмелетке толмағандар арасындағы құқық бұзушылық пен қатыгездіктің көбеюі - бұл, әлеуметтік әл-ауқаттың төмендігінен сапалы білім мен лайықты өмір сүруге қаражаттың жетіспеушілігінен болып отыр.

Зерттеудің мақсаты - жаһандану дәуіріндегі әлеуметтік-гуманитарлық білімнің дүниетанымдық басымдықтарын анықтау. Зерттеудің маңыздылығы модернистік көзқараспен қатар өркениеттік тәсілді өзектендіруге тікелей байланысты. Теориялық және эмпирикалық та^даудың нәтижелері қазақстандық қоғамдағы әлеуметтік дағдарыстардың күшеюін, білім мен мәдениет, Аүниетаным құндылықтары тұрғысынан елдің жастардың әлеуетінің стратификациясын, ұрпақтар арасындағы алшақтықтың артып келе жатқанын көрсетеді.

Жас ұрпақтың қажеттікіктерін көтеретін қуатты экономика ғана әлеуметтік дағдарыстармен күресуге жағдай жасай алады. Білім мен мәдениеттің жоғары деңгейі, жастардың интелмектуалды және ғылыми әлеуеті тек экономикалық өсу жағдайында және қоғамның жоғары адамгершілік ахуалы жағдайында жасалуы мүмкін.

Түйін сөздер: жастар, әлеуметтік-гуманитарлық білім, жаһандану, дүниетанымдық, басымдықтар, нарықтық қоғам, рационализация.

\section{Введение}

В XXI веке масштабы глобализации влияют на социально-экономическое и культурно-духовное развитие стран мирового сообщества. Глобализация усиливает дифференциацию между государствами по уровню открытия и внедрения инновационных технологий не только в экономической сфере, но и в социальной. Высшие учебные заведения при подготовке кадров учитывают спрос современного рынка труда. Инвестиционная политика Казахстана направлена на максимальное вложение в систему подготовки технических кадров. Технологизация общества также влияет на процесс подготовки специалистов социально-гуманитарного направления, возникает необходимость использования комбинированного подхода при обучении специалистов нового формата.

Страны Европы рассматривают Болонский процесс как важнейшую составляющую стратегии создания самой конкурентоспособной в мире экономики, основанной на знаниях. Присоединение казахстанской системы образования к европейскому образовательному пространству произошло в 2010 году с подписанием Болонской Декларации. Интеграционные процессы способствует унификации образовательных стандартов по подготовке кадров. Назрела пот- ребность в усилении роли гуманитарного образования в подготовке специалиста нового формата. Положительным моментом реализации принципов Болонского процесса являются интернализация содержания образования, достаточно высокий уровень овладения иностранным языком выпускниками, хорошие навыки применения информационно-коммуникационных технологий на практике и умение строить межличностные отношения. Нынешнее поколение отличается рациональным поведением и это необходимо для современного рыночного человека. С другой стороны, погоня за приобретением качеств, диктуемых рыночными отношениями, влияет на изменение социальных ценностей человека. Усиление конкуренции как следствие автоматизации и цифровой экономики диктует новые модели поведения. Освоение новых технологий, инноваций, знание различных компьютерных программ, иностранных языков для молодежи выходит на первый план. Такие изменения создают единые стандарты образования без учета национальных и ментальных особенностей человека. Какие особенности сохраняют за собой казахстанские вузы? Отличительная особенность казахстанской системы образования заключается в том, что воспитание является важной частью деятельности современных казахстанских вузов. В эту деятельность при- 
влекают преподавателей с помощью создания института эдвайзерства, путем осуществления социальных и воспитательных мероприятий со студентами. В управленческой структуре университетов есть социальные и воспитательные отделы.

Перспективы развития современного социально-гуманитарного образования в Казахстане непосредственно связаны с государственной программой «Духовная модернизация», основные положения которой были изложены в статье Первого Президента страны Н. Назарбаева «Взгляд в будущее: модернизация общественного сознания» (Назарбаев, 2017). Казахстанские ученые оценили программный характер этого документа и своевременность в соответствии изменениями, происходящими в мировом масштабе.

В современных условиях образование становится главной ценностью, неоспоримым фактом становится культ знания и профессионализм граждан. Как утверждает Ульрих Бек, знание приобретает новое политическое значение (Beck, 1992). Информатизация общества способствует быстрому распространению ценности постиндустриальной цивилизации и гражданского общества.

В Казахстане основным стержнем модернизационных изменений становится национальное сознание. Все изменения, происходящие в обществе, ориентированы на учет особенностей национальной культуры. Однако модернизация рассматривается не как переход от национальной модели развития к некой единой, универсальной. Создать свою модель развития в соответствии с особенностями национальной культуры и с учетом уровня развития страны - это основное направление национальной стратегии Казахстана.

\section{Методы исследования}

Исследование перспективы развития социально-гуманитарного образования в эпоху глобализации основано на теоретико-методологическом, сравнительно-историческом и контекстуальном изучении данной проблемы и ориентировано на определение ее важной роли в формировании молодежного потенциала Казахстана.

Молодежь Казахстана стала более прагматичной в условиях глобализации и капитализации экономики. Как свидетельствуют многочисленные исследования среди молодежи, традиции воспринимаются ими как устаревшее отношение к действительности, а ценности личностной свободы - главной целью жизни (Абдикерова, 2017; Садырова, 2018).

Произошла переоценка ценностей - материальное превалирует, карьера ставится выше семьи, а свободные отношения культивируются как самый удобный способ безответственности за судьбу другого человека. Многие молодые люди $(34 \%)$ считают, что «гражданский брак» (сожительство) - это новая модель семьи, а 11\% вообще ставят под сомнение семейные ценности (Жаназарова, 2018). Серьезная трансформация казахстанского общества приводит к ослаблению института семьи и семейно-брачных отношений и институализации монородительской семьи. Все эти тенденции ориентируют социально-гуманитарные науки на изучение природы этих изменений и занятие повышением статуса института семьи с учетом духовно-культурных ценностей старшего поколения. Переоценка многих ценностей, стремительное снятие границ, вызовы, которые нависли над современным обществом, актуализируют необходимость своего культурного фундамента и национального самосознания, выраженного в культурных кодах. Культурный код нации - это набор образцов и стереотипов на уровне общественного бессознательного. Разрушая архетипы, подменяя их на привнесенные извне, можно низвести любую нацию до низшего уровня (Кылышбаева, Масалимова, 2018).

В глобальном мире «связь между людьми и их культурами, включая их идеи, ценности, образ жизни, росла и углублялась беспрецедентными темпами» (Кумаравадивелу, 2008). Под влиянием глобализации общественной жизни в Казахстане современный подход к социализации личности стал доминирующим по отношению к традиционно сформированному мышлению и восприятию действительности. Либерализация экономики и сопутствующие изменения сформировали у молодежи твердое убеждение о важности личной свободы и ответственности. При этом бедность стала ассоциироваться с нежеланием развиваться, трудиться и взять свою жизнь под личный контроль. Хотя здесь можно было бы упомянуть не только личностные, но и институциональные проблемы. Приравнивая возможности населения к основным общественным благам и формируя основу общества среднего класса, можно добиться определенных успехов в либерализации экономической системы. Желание быстро осуществить процесс либерализации с участием только более успешной части населе- 
ния будет увеличивать число беднейших групп, не обладающих ни материальным, ни духовным ресурсом для осуществления этой цели. Сегодня наиболее продвинутая часть молодежи использует позитивное влияние глобализации для своего становления и личностного роста, в то время как неуспешные становятся аутсайдерами и пополняют количество маргинальных слоев общества, угрожая социальной безопасности государства. Для обогащения содержания молодежного потенциала страны гуманистическими ценностями требуется активная деятельность институтов образования. В соответствии с задачами государственной программы «Духовная модернизация» социальным институтам необходимо заниматься духовной социализацией молодежи, актуализировать передовые национальные традиции и ценности, а также формировать восприятие национальной традиции как самобытный, уникальный, а не архаичный элемент культуры. Перспективы развития социально-гуманитарных дисциплин на данном этапе развития связаны с актуализацией передовых национальных традиции, ценностей, с необходимостью выбора модели развития национальной культуры в условиях глобализации, не идти на поводу универсализации культуры и бороться с негативными последствиями глобализации.

В настоящее время патриотический акт «Мәңгілік ел», принятый 17 января 2014 года в Послании Назарбаева Н.А. «Казахстанский путь-2050: единая цель, единые интересы, единое будущее» (2014) выступает приоритетным направлением фундаментальных и прикладных проектных исследований в области социальногуманитарных наук Казахстана. Общенациональная идея «Мәңгілік ел» призывает граждан быть патриотами своей страны, бережно относиться к общему историческому наследию, приумножать культурное многообразие народа Казахстана, следовать принципу развития государственного языка как основы консолидации общества, трехъязычия как главного условия конкурентоспособности нации.

\section{Основная часть}

Глобализация приближает индивиды, народы и нации, формируя планетарное сознание, ломая этнические, национальные, расовые, религиозные и другие различия между людьми, создает ощущение размытости, однообразия. Такого рода изменения происходят быстрее с распространением рыночных ценностей, раци- онализацией общественной жизни. Для американца и западного человека последствие глобализации не так болезненно, как для восточного человека, который вынужден терять цивилизационные ценности и идентификацию. Технология социального партнерства, распространяемая между взаимодействующими сторонами, приходит в противоречие с традиционными представлениями, формирующими иерархизированные социальные отношения между определенными социальными группами, особенно сильно проявляющимися в половом, возрастном, статусном и др. различий. Нельзя недооценивать позитивное влияние глобализации на развитие общества. Однако для развивающихся стран, вроде Казахстана, ее влияние становится негативным в связи с несформированностью цивилизованных рыночных отношений и отсутствием правового поля для его эффективного развития. Двойственность, проявляющаяся в поведении молодежи в связи с диалектикой традиционного и инновационного в современных условиях, требует, в первую очередь, сохранения национальных традиций и ценностей, как сердцевины мировоззренческих взглядов, и определения собственных позиции к новым глобальным ценностям, выступающим в роли безальтернативного путеводителя прогресса и человеческой свободы.

С получением независимости в 1991 году Казахстан как молодое постсоветское государство предпринимает ряд шагов в направлении возрождения национальной культуры. Государственная программа «Культурное наследие» (2004), Программа «Халық тарих толқынында» (2013), Программа духовной модернизации «Рухани жаңғыру» (2017) тесно взаимосвязаны между собой. Каждая из них имеет свои приоритеты в сохранении ценностей национальной культуры. Культурное наследие было направлено на восстановление историко-культурных памятников и объектов на территории Казахстана, «Халық тарих толқынында» - изучение документов из ведущих мировых архивов, посвященных истории нашей страны, «Рухани жаңғыру»- изменение общественного сознания, сохранение культуры, собственного национального кода. Все эти государственные проекты были направлены на сохранение и возрождение национальной культуры и тесно связаны с еще не менее важным проектом «Интеллектуальная нация-2020» (2008). Социально-гуманитарная наука, следуя призывам государства, занималась актуализацией среди населения передовых национальных традиций, ценностей, поиском но- 
вой модели культуры в условиях глобализации, учитывая национальную специфику, чтобы не идти на поводу универсализации культуры, бороться с негативными последствиями глобализации. Тоффлер в работе «Третья волна» утверждает, что каждая культура будет подходить к результату информационной революции, то есть к «третьей волне» со своей психологией, со своим собственным национальным характером, развившимся на протяжении веков. «Третья волна» будет содержать в себе много культур (Тоффлер, 1980; Бурлацкий, 1989). Возможно, в скором будущем и наша культура будет существовать в новой цивилизации наравне с другими, сохраняя свои особенности, но качественно улучшенные и обогащенные, соответственно духу времени.

Казахстан как развивающееся государства находится все еще на второй волне, если говорить языком Тоффлера, однако в условиях глобализации информатизация общества способствует быстрому распространению ценностей третьей волны, то есть постиндустриальной цивилизации.

Парадигмальность и историчность научной картины мира требует реального соответствия методологии социально-гуманитарных наук духу времени и специфике местности. Это означает, в первую очередь, определения мировоззренческих приоритетов, исходя из конкретноисторической специфики. «Методологические директивы» (как и вся наука в целом) не являются статичными, неизменными, а всегда носят конкретно-исторический характер (Философия науки, 2006). Помимо временного фактора здесь важную роль играет ментальный, обусловленный культурно-психологическими, социальнорелигиозными, политико-экономическими и другими различиями.

Резко усиливающееся расслоение общества на богатых и бедных, появление промежуточных социальных слоев усиливает раздробленность социальных позиций, ценностей, мотивов, интересов и потребностей граждан. Люди, жившие в условиях жесткой идеологии, теперь оказываются перед лицом новой социальной реальности, где ценят индивидуальную свободу и демократическую культуру. В этих условиях представители социально-гуманитарных наук остро ощущают необходимость, с одной стороны, конструирования социума в контексте данной культуры, с другой стороны, с учетом роли индивидуальности (Бергер, 1996). Социальная реальность меняется так быстро, что существующий «идеологический вакуум», то есть отсут- ствие системы основополагающих ценностей государства вместо привнесенных демократических лозунгов ослабляет связь настоящего и прошлого, все больше отдаляет разные поколения друг от друга.

Перед социально-гуманитарной наукой стоит задача определения системы актуальных методологических парадигм, обеспечения собственной социальной идеей, сильных традиций и ценностей, разделяемых большинством населения. В процессе интеграции в мировую образовательную систему современный казахстанский опыт должен быть совмещен как с традициями и лучшими образцами и технологиями обучения, унаследованными от прежней системы образования, так и с собственно мировыми стандартами. Попытка унификации культуры в условиях усиления интеграционных процессов снижает эффективность институциональной интеграции, так как порождает неравные стороны социального взаимодействия. Изучение и творческое использование опыта предыдущих поколений, впитывание в себя культуры родного народа, продолжение культурно-исторических традиций отцов - все это передается молодежи через воспитательные мероприятия, организованные учреждениями культуры и образования, в том числе и высшими учебными заведениями. Многонациональный состав народа Казахстана, наличие традиционных и прогрессивных ценностей в менталитете населения, стремление к свободе и признание силы власти, толерантность, все это способствует эффективности использования интегральной модели в сфере образования. Это означает, что казахстанская цивилизация должна быть открыта к позитивным ценностям западной рационалистической и восточной традиционной культуры.

\section{Результаты и обсуждение}

Осбовождение культуры от идеологизации в современных условиях Казахстана благотворно повлияло на широкое применение в сфере социально-гуманитарных наук понятия «социальной технологии», которая в отличие от «методики», помимо научно-образовательного аспекта обучения, учитывает и культурное сознание обучающихся, и в целом социума. В поведении, деятельности отдельных личностей, социальных общностей можно увидеть культуру общества, природу социального порядка, воплощенные в живых социальных технологиях. В современных условиях следует адаптировать вертикаль- 
ную, иерархически организованную структуру социальных взаимоотношений казахстанского общества к горизонтальным, гражданским формам отношений.

Немецкий исследователь модерна, автор книги «Рефлексивная модернизация» и «Общества риска» Ульрих Бек использует термины «первичный модерн» и «вторичный модерн». Первичный модерн характеризует страны, живущие в закрытых национальных государствах («контейнерная теория). Рост глобальных и транснациональных организаций, транснационального государства характеризует страны, относящиеся к вторичному модерну (Beck\&Grande, 2010; Beck\&Sznaider, 2005;2006). Идея космополитизма, затрагиваемого Ульрихом Беком, характеризуется распространением транснациональной идентичности. В наибольшей степени транснациональность фиксируется в приграничных регионах Казахстана (на севере и юге страны), где постоянно происходит взаимодействие населения, принадлежащего разным государствам (Казахстан-Россия, Казахстан-Узбекистан) (Национальные стратегии модернизации, 2018). Транснациональная идентичность характерна также более образованной части молодежи Казахстана. Учитывая региональные, социальные, культурные, религиозные особенности граждан, в том числе молодого поколения, специалисты социально-гуманитарной науки занимаются изучением эффективного и безболезненного внедрения гражданских форм сотрудничества в иерархически организованный социум.

2020 г. был объявлен «годом волонтера» в Казахстане и, в связи с этим, государством предпринимаются определенные шаги по развитию гражданской активности населения. В настоящее время в стране действуют более 200 волонтерских организаций, в которых участвуют более 50 тыс. активных волонтеров (Волонтерство, 2020). Волонтерство в Казахстана постепенно принимает общенациональный масштаб. Необходимо придумать механизмы постепенной интеграции молодежи в социальную жизнь общества. Нехватку полезной информации социально-психологического, материально-экономического характера остро ощущают молодые люди, относящиеся к группам риска. Совершения ошибки, по различным причинам, не должно стать причиной их становления аутсайдерами в обществе. Социальная безопасность общества требует быстрого реагирования и немедленного решения их проблем. Участие в волонтерской деятельности должно стать обязательной частью соци- альной реабилитации молодежи с комплексом жизненных неудач и психологических проблем. Необходимо привлекать внимание молодежи на важность социальных мероприятий различного уровня, активно адаптировать к социальной действительности, заниматься актуализацией гражданских ценностей в обществе. Таким образом, сознательное привлечение граждан в общественно полезную деятельность приходит в нашу жизнь наравне с традиционно сформированным поведением, осуществляющим акты милосердия, доброты с помощью традиционных ценностей. Сохранение роли традиционных регуляторов поведения в условиях информационного общества ни в коем случае не должно идти в противоречие с формированием гражданского сознания населения. Восприятие традиции как ценностей, а не как устаревших элементов исторического развития, способствует формированию человека, как существа, соединяющего в себе разум и чувства рациональных и иррациональных компонентов поведения.

Существует историческая преемственность между теоретическими подходами разных времен в социологии. Это очевидно во взглядах М. Вебера, который характеризует современный мир как «железную клетку рациональных систем, из которой невозможно выбраться», и Э. Гидденса, который рассматривает «современный мир как «жестокая сила» (juggernaut)», тем самым показывает неизбежность формирования разумного человека в условиях технологизации и цифровизации общества. Однако, Гидденс считает мир после модерна миром возвращения к обществу морали» (Ритцер, 2018). Хочется сказать, что цивилизационные пути развития Запада и Востока должны привести к общему результату с разными путями, учитывая различность экономического и культурного развития. Поэтому Казахстан в лице восточной страны будет придерживаться идеологии открытости к позитивным ценностям западной рационалистической и восточной традиционной культуры. Социально-гуманитарная наука Казахстана может предложить модели социализации молодежи в условиях глобализации, информатизации общества с учетом местных, локальных и региональных ценностей казахстанского общества.

\section{Заключение}

Основная цель высшего образования Казахстана в условиях глобализации - формирование профессиональной мобильности молодежи. 
Однако все больше становится уход из страны образованной, знающей несколько языков, профессионально грамотной, компетентной, социально и профессионально мобильной молодежи, говоря языком 3. Баумана, «живущих в мире глобальной мобильности» (Бауман, 2004). Существует проблема «утечки мозгов».

Евразийская теория сегодня выступает одной из наиболее привлекательных парадигм развития для постсоветских стран, в том числе и для Казахстана, которая опирается на культурное единство народов Евразии.

Сегодняшняя реальность показывает, что первым условием модернизации нового типа для Казахстана должно стать сохранение собственного национального кода. Основной приоритет духовной модернизации - это сохранение внутреннего ядра национального «Я» означает развиваться в рамках парадигмы культурной дифференциации (Хантингтон), несмотря на появления некоторых гибридных форм в духе глокализации (Робертсон), в том числе культурной конвергенции, наблюдаемых явлениями макдональдизации, американизации и капитализации экономики (Рисмен, 2018).

Многие современные исследователи рассматривают модернизацию как переход от национальной модели развития к некой единой, универсальной. Как утверждает Хантингтон, «тезис о возможности «универсальной цивилизации» это западная идея. Она находится в прямом противоречии с партикуляризмом большинства азиатских культур, с их упором на различия, отделяющие одних людей от других» (Хантингтон, 2007). Как показывает практика, разные регионы и страны выбирают свои модели развития, которые отражаются в государственной политике этих стран.
Социально-гуманитарная наука Казахстана определяет мировоззренческие приоритеты в соответствии с национальным интересом и будет воспитывать молодежь гражданской активности, сохраняя при этом культурные ценности страны, обогащая ее новым качественным содержанием. Во многих высших учебных заведениях Казахстана большое внимание уделяется духовно-нравственному воспитанию молодежи наравне с научно-исследовательской и образовательной деятельностью. В Казахском национальном университете имени аль-Фараби в учебный процесс внедрены такие социально-воспитательные проекты как, «Айналаңды нұрландыр!» («Освети мир вокруг себя»), «100 кітап» (100 книг»), издание серий книги «Өнегелі өмір», цель которого - воспитание подрастающего поколения на примере жизни и деятельности выдающихся отечественных деятелей и ученых-педагогов, внесших значительный вклад в развитие страны.

Современный Казахстан представляет собой пример полиэтнического общества с многообразием культур, религий и языков, поэтому ведущей государственной политикой является сохранение гражданского мира и межнационального согласия. В условиях глобализации основным мировоззренческим приоритетом для социально-гуманитарных наук Казахстана станет актуализация сохранения культурного многообразия народов Евразии («Казахстан как евразийская страна»), развитие гражданской идентичности населения. Гражданская идентичность не противоречит сохранению национальной идентичности. По крайней мере, на данном этапе развития казахстанского общества национальные приоритеты являются важным направлением общественного развития.

\section{Литература}

Бауман 3. Глобализация. Последствия для человека и общества: Пер. с англ. - М.: Издательство «Весь Мир», 2004. $188 \mathrm{c}$.

Бергер П. Приглашение в социологию. гуманистическая перспектива. - М.: Аспект Пресс, 1996. - 166с.

Beck U, Edgar G. "Varieties of Second Modernity: The Cosmopolitan Turn in Social and Political Theory and Research." British Journal of Sociology. - 2010. 61(3). - pp. 409-443; Beck U, Natan S. “Cosmopolitan Sociology.” 2005 -pp. 157-161; Beck U, Natan S. "Unpacking Cosmopolitanism for the Social Sciences: A Research Agenda." British Journal of Sociology. - 2006. $-57(1) .-$ pp. 1-23.

Beck U. Rick society. Towards a new modernity. SAGE Publications. London, Newbury Park, New Delhi, 1992. - P.23.

В Казахстане 2020 год объявлен Годом волонтера //https://kursiv.kz/news/obschestvo/2019-09/

Государственная программа «Культурное наследие». - Астана, 2006-2011 годы. //https://e-history.kz/ru/contents/ view/1568

Жаназарова 3.Ж. Семья в современном Казахстане: состояние и перспективы развития // Модернизационная стратегия Казахстана в социологическом измерении: новые ценности, новая система координат, новое время. Сборник материалов VI Конгресса социологов Казахстана. - Астана, 2018. - С. 221. 
Кылышбаева Б.Н., Масалимова А.Р. Поиск консолидирующих культурных кодов казахстанского общества // Модернизационная стратегия Казахстана в социологическом измерении: новые ценности, новая система координат, новое время. Сборник материалов VI Конгресса социологов Казахстана. - Астана, 2018. - С. 126.

Kumaravadivelu B. Cultural globalization and language education. New Haven, CT: Yale University Press, 2008. - P. 33.

Назарбаев Н. Взгляд в будущее: модернизация общественного сознания». 12 апреля 2017 года. https://online.zakon.kz/ Document/

Народ в потоке истории // https://e-history.kz/kz/contents/view/331

Национальная идея» - «Мәңгілік ел!» // http:/www.kst.adilet.gov.kz/ru/articles-inner/nacionalnaya-ideya-mngilik-el-0

Национальные стратегии модернизации:достижения и перспективы. - Астана, 2018. - С. 224.

Программа "Интеллектуальная нация - 2020 //Zakon.kz. 30 января 2008 года.

Ritzer G, Stepnisky J. Sociological theory 10th edition, Sage. Los Angeles, London, New Delhi,Singapore, Washington DC., Melbourn. - 2018. - P. 593

Ритцер Дж. Социологические теории. - Астана, 2018. - С. 146; С. 587

Система высшего образования и работодатели: на пути к стратегическому партнерству: монография / отв. ред. проф. Г.О. Абдикерова. - Алматы: Қазақ университеті, 2017. - С. 98; Профессиональный потенциал выпускников вузов и молодых специалистов Казахстана: модели трудоустройства. Монография /отв. ред. проф. М.С. Садырова. - Алматы: Қазақ университеті, 2018. - С. 131.

Тоффлер Э. Третья волна. Перевод на русский язык: А. Мирер, И. Москвина-Тарханова, В. КулагинаЯрцева, Л. Бурмистрова, К. Бурмистров, Е. Комарова, А. Микиша, Е. Руднева, Н. Хмелик. - Москва, 2004. // Электронная публикация. Центр гуманитарных технологий. 27.01.2011. URL: https:/gtmarket.ru/laboratory/basis/4821; Бурлацкий Ф. Новое мышление. - М., 1989. - С. 22-23.

Философия науки в вопросах и ответах: Учебное пособие для аспирантов / В.П. Кохановский [и др.]. - Ростов на Дону: Феникс, 2006. - С. 155-156.

Хантингтон С. Столкновение цивилизации // https:/gtmarket.ru/laboratory/expertize/2007/2498

\section{References}

Baýman 3. (2004) Globalızatsıa. Posledstvı1a dlia cheloveka 1 obestva [Globalization. Consequences for man and society]. M.: Ves Mir Publishing House, 188 p.

Berger P. (1996) Prıglashenıe v sotsılogıý. gýmanıstıcheskaı perspektıva [Invitation to sociology. humanistic perspective]. M.: Aspect Press, 166 p.

Beck U, Edgar G. (2010) Varieties of Second Modernity: The Cosmopolitan Turn in Social and Political Theory and Research // British Journal of Sociology, 61(3), P. 409-443.

Beck U, Natan S. (2005) Cosmopolitan Sociology, P. 157-161;

Beck U, Natan S. (2006) Unpacking Cosmopolitanism for the Social Sciences: A Research Agenda// British Journal of Sociology, 57(1), P. 1-23.

Beck U. (1992) Rick society. Towards a new modernity. SAGE Publications. London, Newbury Park, New Delhi, 23 p.

F1losofi1a naýk1 v voprosah 1 otvetah (2006). Ýchebnoe posobie dlıa aspırantov [Philosophy of Science in Questions and Answers. Textbook for graduate students]. P. Kohanovsky et al., Rostov on Don: Phoenix, P. 155-156.

Gosýdarstvenna1a programma «Kýltýrnoe nasledıe» [State program "Cultural heritage”]. Astana, 2006-2011//https://e-history. $\mathrm{kz} / \mathrm{ru} /$ contents/view/1568

Hantıngton S. Stolknovenıe tsıv1lızats11 [Clash of Civilization]. https://gtmarket.ru/laboratory/expertize/2007/2498

Kylyshbaeva B.N,Masalımova A.R. (2018) Poısk konsolıdırýıýlh kýltýrnyh kodov kazahstanskogo obestva [Search for Consolidating Cultural Codes of Kazakhstani Society]. Modernization Strategy of Kazakhstan in Sociological Dimension: New Values, New Coordinate System, New Time. Collection of materials of the VI Congress of Sociologists of Kazakhstan, Astana, $126 \mathrm{p}$.

Kumaravadivelu B. (2008). Cultural globalization and language education. New Haven, CT: Yale University Press, 33 p.

Nazarbaev N. Vzgliad v býdýee: modernızatsıa obestvennogo soznanı1a [Looking into the future: modernization of public consciousness]. April 12, 2017. https://online.zakon.kz/Document/

Natsıonalnye strateg11 modernızats11:dostijenı1a 1 perspektıvy (2018) [National modernization strategies: achievements and prospects]. Astana, $224 \mathrm{p}$.

Natsıonalnaı 1de1a - «Máńgilik el!» [National idea -’Mangilik el!’]. http://www.kst.adilet.gov.kz/ru/articles-inner/ nacionalnaya-ideya-mngilik-el-0

Narod v potoke 1stor11 [People in the stream of history]. https://e-history.kz/kz/contents/view/331

Programma "Intellektýalnaia nats11a - 2020 [Program "Intellectual Nation - 2020]. Zakon.kz., January 30, 2008.

Rittser Dj. (2018) Sotsiologicheskie teor11 [Sociological theories]. - Astana, 587 p.

Rizer G, Stepnisky J. (2018) Sociological theory 10th edition. Sage. Los Angeles,London, New Delhi,Singapore, Washington DC., Melbourn, 593 p.

Sistema vysshego obrazovanı1a 1 rabotodatelı: na pýtı k strategıcheskomý partnerstvý (2017): monografi1a / otv. red. prof. G.O. Abdikerova [The higher education system and employers: on the way to strategic partnership: monograph/ed. prof. G.O. Abdikerova]. Almaty: Kazakh University, 2017, 98 p. 
Professionalnyı potentsıal vypýsknıkov výzov 1 molodyh spetsıalıstov Kazahstana: modelı trýdoýstroıstva. (2018) Monografi1a /otv. red. prof. M.S.Sadyrova [Professional potential of university graduates and young specialists in Kazakhstan: models of employment. Monograph / ed. prof. M.S. Sadyrova]. Almaty: Kazakh University, 2018, 131 p.

Toffler E. (2004) Tretıa volna. Perevod na rýsskı1 1azyk: A. Mırer, I. Moskvına-Tarhanova, V. Kýlagına-Iartseva, L. Býrmıstrova, K. Býrmıstrov, E. Komarova, A. Mıkısha, E. Rýdneva, N. Hmelık [The third wave. Translation into Russian: A. Mirer, I. MoskvinaTarkhanova, V. Kulagina-Yartseva, L. Burmistrova, K. Burmistrov, E. Komarova, A. Mikish, E. Rudneva, N. Khmelik]. Moscow. 2004. // Electronic publication. Center for Humanitarian Technologies. 27.01.2011//URL: https://gtmarket.ru/laboratory/basis/4821.

Býrlatsk11 F. (1989) Novoe myshlenıe [New thinking]. Moscow, P. 22-23.

V Kazahstane 2020 god obiavlen Godom volontera [In Kazakhstan, 2020 is declared the Year of the Volunteer ]. //https://kursiv. kz/news/obschestvo/2019-09/

Zhanazarova Z.Zh. (2018) Semıa v sovremennom Kazahstane: sosto1anıe 1 perspektıvy razvit11a// Modernızatsionna1a strategi1a Kazahstana v sotsiologicheskom 1zmerenı: novye tsennostı, novaia sistema koordınat, novoe vremı. Sbornık materialov VI Kongressa sotsiologov Kazahstana [Family in modern Kazakhstan: state and development prospects // Modernization strategy of Kazakhstan in the sociological dimension: new values, new coordinate system, new time. Collection of materials of the VI Congress of Sociologists of Kazakhstan]. Astana, 221 p. 